\title{
FORMULASI KRIM ANTIOKSIDAN DAUN CEMPEDAK (Artocarpus champeden Spreng)
}

\author{
Septi Anggraini ${ }^{1}$, Nur Mita ${ }^{1}$, Arsyik Ibrahim ${ }^{1}$ \\ ${ }^{1}$ Laboratorium Penelitian dan Pengembangan FARMAKA TROPIS Fakultas Farmasi Universitas \\ Mulawarman, Samarinda, Kalimantan Timur \\ Email : septifarmasi21@gmail.com
}

\begin{abstract}
Cempedak (Artocarpus champeden Spreng) is one of the Indonesian native plants. Ethyl acetate extract of cempedak leaves has antioxidant activity with the $\mathrm{IC}_{50}$ value of 4,275 ppm. The aims of this research was to utilize the ethyl acetate extract of cempedak leaves as the main ingredient in the preparation of antioxidant cream. The cream formulas were made in three formulas, where the concentration of ethyl acetate extract of cempedak leaves were made in $1,6 \%, 0,16 \%$ and $0,016 \%$. The formulas were evaluated their physical stability by using the organoleptic test, homogeneity, $\mathrm{pH}$, dispersive power, viscosity, emulsion type and also the stability test by using Freeze Thaw method. The result showed the best preparation of antioxidant cream was the cream with the extract concentration of $0,016 \%$ and the $\mathrm{IC}_{50}$ values are 5,91 ppm before storage and 10,57 ppm after storage.
\end{abstract}

Keywords: Cream, physical stability, antioxidant

\begin{abstract}
ABSTRAK
Cempedak (Artocarpus champeden Spreng) merupakan tumbuhan asli Indonesia. Ekstrak etil asetat daun cempedak memiliki aktivitas antioksidan dengan nilai $\mathrm{IC}_{50}$ sebesar 4,282 ppm. Tujuan penelitian ini adalah untuk memanfaatkan ekstrak etil asetat daun cempedak sebagai bahan utama dalam pembuatan sediaan krim antioksidan. Krim diformulasi dengan membandingkan konsentrasi ekstrak etil asetat daun Cempedak yaitu 1,6\%, 0,16\% dan $0,016 \%$.. Evaluasi fisik meliputi uji organoleptis, homogenitas, $\mathrm{pH}$, daya sebar, viskositas, tipe emulsi dan uji stabilitas dengan metode Freeze Thaw. Hasil yang diperoleh sediaan krim terbaik adalah sediaan krim dengan konsentrasi ekstrak sebesar 0,016\% dengan nilai $\mathrm{IC}_{50}$ sebesar 5,91 ppm sebelum penyimpanan dan 10,57 ppm setelah penyimpanan.
\end{abstract}

Kata Kunci: Krim, stabilitas fisik, antioksidan

\section{PENDAHULUAN}

Tumbuhan cempedak (Artocarpus champeden Spreng) banyak terdapat di daerah yang bercurah hujan cukup besar seperti Kalimantan Timur. Tanaman dengan genus Artocarpus mengandung metabolit sekunder berupa flavonoid yang telah diakui memiliki potensi sebagai antioksidan (Barel, 2009, Pereira, 2013). Berdasarkan hasil penelitian yang telah dilakukan sebelumnya, ekstrak etil asetat daun Cempedak (Artocarpus champeden Spreng) telah tebukti memiliki aktivitas antioksidan sangat kuat, yaitu dengan nilai $\mathrm{IC}_{50}$ sebesar 4,275 ppm (Anggraini, S. dkk, 2015).

Meskipun antioksidan enzimatik telah ada dalam tubuh manusia, namun seiring bertambahnya usia menyebabkan diperlukannya antioksidan dari luar, yang salah satunya adalah untuk mengatasi dampak yang ditimbulkan radikal bebas pada kulit berupa 
kehilangan elastisitas jaringan kolagen dan otot sehingga kulit tampak keriput, terjadinya lipofuchsin atau bintik-bintik pigmen kecoklatan di kulit yang merupakan timbunan sisa pembakaran dalam sel (Anies, 2009). Bentuk sediaan yang umum digunakan pada kulit adalah krim.

Krim adalah sediaan semipadat yang mengandung satu atau lebih bahan obat yang terlarut atau terdispersikan baik dalam emulsi tipe minyak dalam air (m/a) atau air dalam minyak (a/m) (Allen, 2011). Sifat umum sediaan krim adalah mampu melekat pada permukaan tempat pemakaian dalam waktu yang cukup lama sebelum sediaan dicuci dan atau dihilangkan. Krim dapat memberikan efek mengkilap, melembabkan dan mudah tersebar merata, mudah berpenetrasi pada kulit, mudah diusap, dan mudah dicuci dengan air (Anwar, 2012).

Pemilihan basis krim yang baik sangat berpengaruh terhadap hasil dari formula krim secara keseluruhan yang mengandung bahan aktif tertentu termasuk dari bahan alam. Berbagai penelitian telah dilakukan untuk pemilihan basis krim untuk formulasi sediaan untuk bahan alam sebagai kandungan aktifnya, baik dengan menggunakan surfaktan nonionik seperti Tween 60 dan Span 60, maupun surfaktan anionik seperti trietanolamin (Mita, N., 2015). Berdasarkan hasil evaluasi fisik yang telah dilakukan, ternyata penggunaan emulgator kombinasi asam stearat dan trietanolamin $2 \%$ juga dapat memberikan hasil yang baik sebagai basis krim (Anggraini, S. dkk, 2015). Untuk itu dalam formulasi krim ekstrak etil asetat daun Cempedak ini dipilih basis krim dengan menggunakan emulgator kombinasi tersebut. Untuk mengetahui berapa konsentrasi ekstrak yang optimal dan stabil secara fisik ketika diformuasi dalam bentuk sediaan krim, maka dilakukanlah penelitian ini dengan membandingkan konsentrasi ekstrak etil asetat daun Cempedak yaitu $1,6 \%, 0,16 \%$, dan $0,016 \%$.

\section{METODE PENELITIAN}

\section{a. Penyiapan Ekstrak Etil Asetat Daun Cempedak (Artocarpus champeden Spreng)}

Daun Cempedak (Artocarpus champeden Spreng) diperoleh dari perkebunan di Samarinda, Kalimnatan Timur. Simplisia yang telah diperoleh kemudian dibersihkan dari kotoran dandipotong kecil-kecil, kemudian dimaserasi dengan menggunakan pelarut metanol, lalu diuapkan pelarutnya dengan rotary evaporator. Setelah itu ekstrak difraksinasi dengan metode fraksinasi bertingkat menggunakan beberapa pelarut yaitu nheksan dan etil asetat, kemudian hasil fraksi dengan pelarut etil asetat diuapkan di atas waterbath hingga menjadi ekstrak kental.

\section{b. Formulasi Sediaan Krim}

Pembuatan sediaan krim dilakukan dengan melebur fase minyak yaitu asam stearat, vaselin, propil paraben dan BHT di atas penangas air dengan suhu $70{ }^{\circ} \mathrm{C}$. Dilarutkan metil paraben dalam propilenglikol kemudian ditambahkan air dan dipanaskan hingga suhu 80 ${ }^{\circ} \mathrm{C}$ kemudian ditunggu hingga suhu turun ditambahkan trietanolamin. Dimasukkan fase minyak ke dalam lumpang panas kemudian ditambahkan fase air dan dimixer hingga terbentuk massa krim. Ekstrak etil asetat daun Cempedak dicampurkan ke dalam basis setelah suhu mencapai $\pm 55 \square \mathrm{C}$, kemudian diaduk hingga homogen.

\section{c. Evaluasi Fisik Sediaan Krim}

\section{Organoleptis}

Pengujian ini dilakukan dengan menggunakan mikroskop, kaca preparat dan kaca objek. Pengujian dilakukan dengan cara menimbang sejumlah krim. Krim tersebut 
dioleskan pada kaca objek dan ditutup dengan kaca preparat kemudian diamati jika terjadi penggumpalan atau pemisahan.

\section{Uji Daya Sebar}

Pengujian ini dilakukan dengan cara meletakkan krim di atas kaca transparan yang diletakkan di atas kertas grafik kemudian kaca tersebut ditutup dengan kaca transparan yang lain, dibiarkan selama kurang lebih 15 detik dan ditambahkan beban 10, 20, 50, 100, dan 200 g kemudian diamati diameter daerah yang terbentuk.

\section{Uji Tipe Emulsi}

Pengujian dilakukan dengan menggunakan metode pengenceran. Sejumlah krim diteteskan ke dalam $30 \mathrm{~mL}$ air. Krim tipe m/a akan terdistribusi secara merata pada medium air. Krim tipe a/m tidak akan terdistribusi merata pada permukaan air.

\section{Uji pH}

Pengukuran $\mathrm{pH}$ basis krim menggunakan $\mathrm{pH}$ meter. $\mathrm{pH}$ meter dikalibrasi menggunakan larutan $\mathrm{pH} 4$ dan $\mathrm{pH}$ 7. Kemudian diukur $\mathrm{pH}$ basis.

\section{Uji Viskositas}

Pengujian viskositas basis krim menggunakan viskometer Rheosys Cone and Plate dengan kecepatan 5 rpm.

\section{Uji Stabilitas}

Pengujian stabilitas basis menggunakan metode Freez and Thaw dengan menggunakan dua suhu. Pertama basis krim disimpan pada suhu $4^{\circ} \mathrm{C}$ selama 48 jam dan dilanjutkan pada suhu $40^{\circ} \mathrm{C}$ selama 48 jam. Kemudian diamati organoleptis dan homogenitasnya. Pengujian dilakukan hingga 6 siklus.

\section{d. Pengukuran Aktivitas Antioksidan}

\section{Pembuatan larutan stok ekstrak dan variasi konsentrasi}

Ditimbang $20 \mathrm{mg}$ ekstrak etil asetat daun cempedak kemudian dilarutkan dalam 50 $\mathrm{mL}$ metanol, dihomogenkan. Dibuat variasi konsentrasi yaitu 2, 4, 6, 8, 10, 12, 14, 16 ppm dengan mengencerkan larutan stok $40 \mathrm{ppm}$.

\section{Uji Aktivitas Antioksidan}

Ditimbang $4 \mathrm{mg}$ DPPH kemudian dilarutkan dalam $100 \mathrm{~mL}$ metanol hingga homogenkan. Dimasukkan $2 \mathrm{~mL}$ larutan DPPH $40 \mathrm{ppm}$ ke dalam tabung reaksi gelap bertutup. Ditambahkan $2 \mathrm{~mL}$ metanol. Dihomogenkan dengan vortex. Kemudian diukur $\lambda$ maks dengan panjang gelombang 400-600 nm. Didapatkan $\lambda$ maks dan absorbansi blanko.

\section{HASIL DAN PEMBAHASAN}

Formula krim yang dibuat terdiri dari tiga sediaan. Konsentrasi bahan tambahan dalam ketiga sediaan krim adalah sama yang membedakan adalah konsentrasi ekstrak yang digunakan. Berdasarkan pengujian aktivitas antioksidan ekstrak etil asetat daun cempedak diketahui bahwa konsentrasi tertinggi ekstrak dalam menghambat radikal DPPH adalah pada konsentrasi $16 \mathrm{ppm}$, mengacu pada hasil tersebut peneliti membuat formula krim dengan memvariasikan konsentrasi ekstrak yaitu 16.000, 1600 dan 160 ppm yang masingmasing diberi label sebagai F1, F2 dan F3. Ketiga formula basis krim kemudian disimpan selama 4 minggu pada suhu $25^{\circ} \mathrm{C}$ dan uji stabilitas menggunakan metode Freeze and Thaw pada suhu 4 dan $40^{\circ} \mathrm{C}$ selama 6 siklus. Evaluasi sediaan krim meliputi organoleptis, 
homogenitas, $\mathrm{pH}$, daya sebar, viskositas dan tipe emulsi. Hasil uji stabilitas fisik krim terlihat pada Tabel 6.7, peningkatan konsentrasi ekstrak etil asetat daun cempedak mempengaruhi warna dari sediaan krim. Hasil pengamatan F1, F2 dan F3 tidak mengalami perubahan warna, bau dan homogenitas selama penyimpanan.

Tabel 1. Hasil Uji Stabilitas dengan Metode Freeze and Thaw

\begin{tabular}{cccc}
\hline Formula & $\begin{array}{c}\text { Konsentrasi } \\
\text { Ekstrak }(\mathrm{ppm})\end{array}$ & Organoleptis & Homogenitas \\
\hline 1 & 16.000 & Berwarna cokelat tua, membentuk massa krim, bau khas bahan & Homogen \\
2 & 1600 & Berwarna cokelat muda, membentuk massa krim, bau khas bahan & Homogen \\
3 & 160 & Berwarna putih kecokelatan, membentuk massa krim, bau khas bahan & Homogen \\
\hline
\end{tabular}

Berdasarkan pengukuran $\mathrm{pH}$ sediaan krim mengalami peningkatan selama penyimpanan tetapi tidak terlalu berarti (Tabel 2.). $\mathrm{pH}$ dari ketiga formula masuk dalam range $\mathrm{pH}$ kulit yaitu 4,5-6,5 dan $\mathrm{pH}$ sediaan krim diatas $\mathrm{pH}$ basis hal ini dikarenakan penambahan ekstrak etil asetat yang bersifat asam sehingga mampu menurunkan $\mathrm{pH}$ dari sediaan krim. pH sediaan krim yang terlalu basa dapat menyebabkan kulit bersisik.

Tabel 2. Hasil Uji pH Sediaan Krim

\begin{tabular}{ccccccc}
\hline \multirow{2}{*}{ Formula } & \multicolumn{5}{c}{$\mathbf{p H}$} & \multirow{2}{*}{ Rata-Rata } \\
\cline { 2 - 5 } & $\mathbf{H}_{\mathbf{0}}$ & $\mathbf{M}_{\mathbf{1}}$ & $\mathbf{M}_{\mathbf{2}}$ & $\mathbf{M}_{\mathbf{3}}$ & $\mathbf{M}_{\mathbf{4}}$ & \\
\hline 1 & 5,77 & 6,07 & 6,11 & 6,13 & 6,13 & $6,04 \pm 0,2$ \\
2 & 5,26 & 5,78 & 6,13 & 6,15 & 6,20 & $5,90 \pm 0,4$ \\
3 & 6,05 & 6,30 & 6,30 & 6,3 & 6,42 & $6,28 \pm 0,13$ \\
\hline
\end{tabular}

Pengujian viskositas krim menunjukan terjadi perubahan viskositas dari sediaan krim. Faktor-faktor yang mempengaruhi viskositas sediaan krim adalah pengadukan saat membuat krim, zat pengental, surfaktan yang dipilih, proporsi fase terdispersi, dan ukuran partikel, ketika proporsi fase terdispersi menurun maka viskositas akan menurun (Aisyahni, 2012).

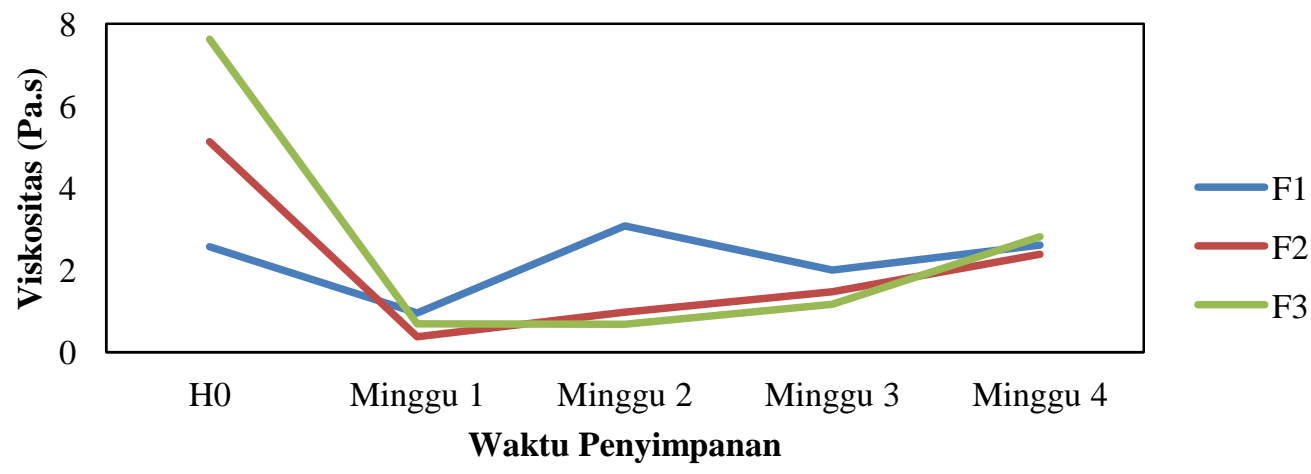

Gambar 1. Kurva Hasil Pengukuran Viskositas Krim 
Hasil yang didapatkan terjadi penurunan viskositas yang besar pada penyimpanan minggu ke 1 (Gambar 1.), formula krim yang memiliki viskositas paling besar adalah formula 3. Viskositas suatu sediaan berbanding terbalik dengan daya sebarnya. Semakin besar viskositas krim maka akan semakin kecil kemampuan sebarnya hal ini sesuai dengan hasil daya sebar krim dimana formula 3 memiliki nilai daya sebar yang paling rendah (Gambar 2).

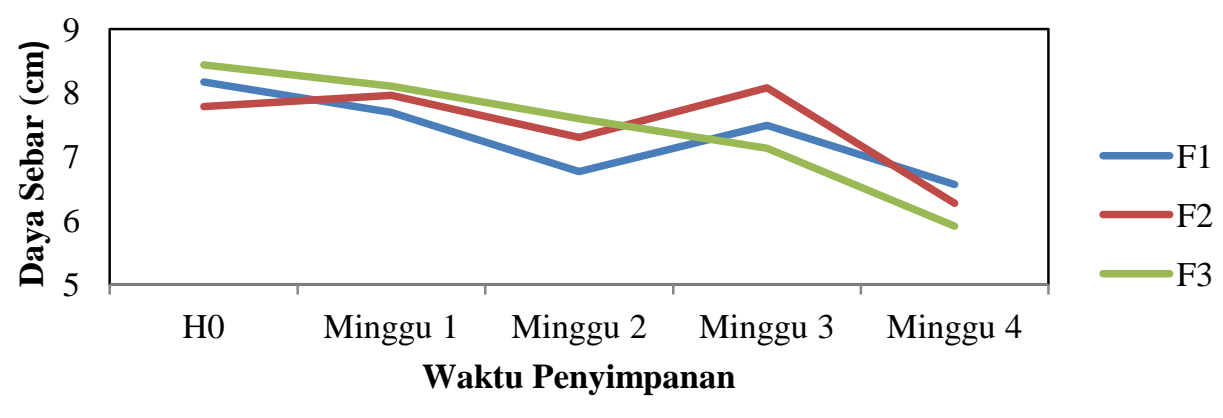

Gambar 2. Kurva Hasil Pengukuran Daya Sebar Krim

Sediaan krim yang telah dibuat kemudian diukur aktivitas antioksidannya pada. Pengujian ini bertujuan untuk mengatahui kemampuan peredaman radikal DPPH oleh sediaan krim yang mengandung ekstrak etil asetat daun cempedak. Berdasarkan pengujian diketahui ketiga formula sediaan krim ekstrak etil asetat daun cempedak memiliki kemampuan peredaman radikal DPPH terlihat pada Gambar 6.5, 6.6, dan 6.7 terjadi peningkatan penghambatan radikal DPPH oleh sediaan krim.

Pengukuran aktivitas antioksidan sediaan menggunakan metode DPPH. Sediaan krim yang telah dibuat diencerkan menggunakan pelarut metanol 1: 2 kemudian disentrifuge selama 10 menit dengan kecepatan $9000 \mathrm{rpm}$. Tujuan pengenceran menggunakan pelarut metanol adalah untuk mengekstraksi senyawa kimia dalam ekstrak yang memiliki aktivitas antioksidan sehingga dapat diukur menggunakan metode DPPH dan dilakukan pemisahan menggunakan sentrifuge, kemudian supernatan yang diperoleh dibuat larutan seri konsentrasi dan diukur aktivitas antioksidannya.

Hasil yang diperoleh ketiga formula krim memiliki aktivitas antioksidan dilihat dari terjadinya penurunan absorbansi dari radikal DPPH setelah direaksikan dengan krim. Absorbansi yang diperoleh kemudian digunakan untuk menghitung persentase inhibisi DPPH oleh sediaan krim (Gambar 3.). Terjadi peningkatan persen inhibisi seiring dengan peningkatan konsentrasi larutan uji. 

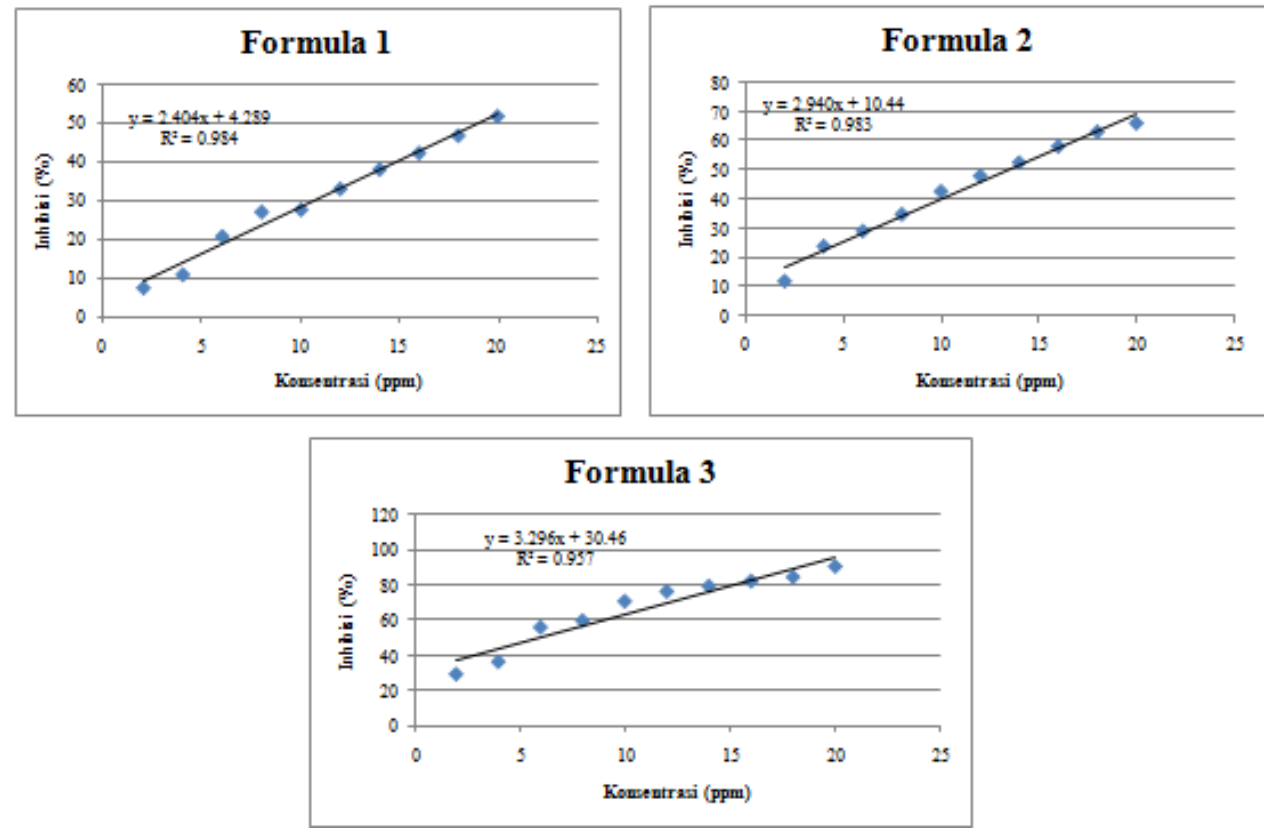

Gambar 3. Kurva Hasil Pengukuran Aktivitas Antioksidan Sediaan Krim

Nilai $\mathrm{IC}_{50}$ merupakan konsentrasi larutan uji dalam menghambat sebesar 50\% radikal DPPH. Pada penelitian ini pengujian aktivitas antioksidan sediaan krim dilakukan sebelum penyimpanan dan setelah penyimpanan. Tujuan dilakukan dua kali pengukuran adalah untuk melihat apakah terjadi perubahan aktivitas antioksidan selama penyimpanan. Hasil yang didapatkan $\mathrm{IC}_{50}$ sediaan krim yang paling besar adalah sediaan krim formula $\mathrm{F} 3$ yang merupakan formula krim dengan konsentrasi ekstrak paling kecil yaitu 0,016\% (Tabel 3 dan 4). Sediaan krim dengan konsentrasi ekstrak paling besar memiliki nilai $\mathrm{IC}_{50}$ paling kecil hal ini disebabkan karena pada konsentrasi yang pekat ion-ion dengan muatan berlawanan dalam suatu sistem akan bergabung membentuk pasangan ion (ion pair) sehingga menyebabakan terjadinya ionisasi tidak sempurna. Suatu larutan mempunyai konsentrasi efektif yang lebih kecil dibandingkan konsentrasi nyata (konsentrasi stoikiometri) zat terlarut karena beberapa ion secara efektif tidak berperan lagi karena adanya gaya elektrostatik. Pengenceran dalam jumlah besar menyebabkan ion-ion akan terpisah jauh sehingga tidak terjadi interaksi satu sama lain yang menyebabkan konsentrasi efektif setara dengan konsentrasi stoikiometri (Sinko, 2006).

Tabel 3. Hasil Uji Aktivitas Antioksidan Sebelum Penyimpanan

\begin{tabular}{cccccc}
\hline \multicolumn{1}{c}{ F1 } & \multicolumn{2}{c}{ F2 } & \multicolumn{2}{c}{ F3 } \\
\hline $\begin{array}{c}\text { Konsentrasi } \\
(\mathrm{ppm})\end{array}$ & \% Inhibisi & $\begin{array}{c}\text { Konsentrasi } \\
(\mathbf{p p m})\end{array}$ & \% Inhibisi & $\begin{array}{c}\text { Konsentrasi } \\
(\mathbf{p p m})\end{array}$ & \% Inhibisi \\
\hline 2 & 7,68 & 2 & 11,51 & 2 & 29,37 \\
4 & 11,13 & 4 & 23,6 & 4 & 36,46 \\
6 & 20,92 & 6 & 28,79 & 6 & 56,43 \\
8 & 27,25 & 8 & 34,55 & 8 & 59,88 \\
10 & 27,83 & 10 & 42,41 & 10 & 71,01 \\
12 & 33,2 & 12 & 47,79 & 12 & 76,58 \\
14 & 38,2 & 14 & 52,4 & 14 & 79,65 \\
16 & 42,41 & 16 & 57,96 & 16 & 82,15 \\
18 & 46,89 & 18 & 63 & 18 & 84,80 \\
20 & 51,83 & 20 & 65,93 & 20 & 90,84 \\
\hline $\mathrm{IC}_{50}=19,01$ & $\mathrm{ppm}$ & $\mathrm{IC}_{50}=13,46 \mathrm{ppm}$ & $\mathrm{IC}_{50}=5,91 \mathrm{ppm}$ \\
\hline
\end{tabular}


Tabel 4. Hasil Uji Aktivitas Antioksidan Setelah Penyimpanan

\begin{tabular}{cccccc}
\hline \multicolumn{1}{c}{ F1 } & \multicolumn{3}{c}{$\mathbf{F 2}$} & \multicolumn{2}{c}{$\mathbf{F 3}$} \\
\hline $\begin{array}{c}\text { Konsentrasi } \\
(\mathrm{ppm})\end{array}$ & \% Inhibisi & $\begin{array}{c}\text { Konsentrasi } \\
(\mathbf{p p m})\end{array}$ & \% Inhibisi & $\begin{array}{c}\text { Konsentrasi } \\
(\mathbf{p p m})\end{array}$ & \% Inhibisi \\
\hline 2 & 2,49 & 2 & 15,48 & 2 & 19,21 \\
4 & 3,38 & 4 & 21 & 4 & 38,61 \\
6 & 4,27 & 6 & 22,24 & 6 & 42,35 \\
8 & 5,16 & 8 & 26,87 & 8 & 45,02 \\
10 & 6,58 & 10 & 29,36 & 10 & 49,11 \\
12 & 7,65 & 12 & 31,32 & 12 & 55,16 \\
14 & 8,72 & 14 & 32,56 & 14 & 60,32 \\
16 & 9,78 & 16 & 37,37 & 16 & 63,52 \\
18 & 12,1 & 18 & 42,17 & 18 & 66,54 \\
20 & 13,34 & 20 & 44,3 & 20 & 70,64 \\
\hline $\mathrm{IC}_{50}=82,08 \mathrm{ppm}$ & $\mathrm{IC}_{50}=23,97 \mathrm{ppm}$ & $\mathrm{IC}_{50}=10,57 \mathrm{ppm}$ \\
\hline \multicolumn{7}{r}{}
\end{tabular}

Tabel 5. Hasil Uji Aktivitas Antioksidan Ekstrak Etil Asetat Daun Cempedak

\begin{tabular}{ccc}
\hline Konsentrasi (ppm) & \% Inhibisi & IC $_{\mathbf{5 0}}$ \\
\hline 2 & 37,97 & \\
4 & 48,57 & \\
6 & 56,76 & $\mathrm{y}=4,253 \mathrm{x}+31,79$ \\
8 & 67,59 & $\mathrm{IC}_{50}=4,282 \mathrm{ppm}$ \\
10 & 77,18 & \\
12 & 84,69 & \\
14 & 92,34 & \\
16 & 95,44 & \\
\hline
\end{tabular}

Nilai $\mathrm{IC}_{50}$ mengalami penurunan setelah ekstrak dimasukkan ke dalam basis krim. Nilai IC $_{50}$ ekstrak adalah 4,282 ppm (Tabel 5.) tetapi setelah diformulasikan menjadi sediaan krim terjadi penurunan. Terlihat bahwa F3 memiliki nilai $\mathrm{IC}_{50}$ yang lebih kecil dari formula yang lainnya. Penurunan aktivitas antioksidan diduga dipengaruhi oleh bahanbahan dalam basis yang dapat mempengaruhi aktivitas ekstrak, proses pelepasan bahan aktif serta pengaruh waktu difusi ekstrak untuk lepas dari basis. Semakin lama waktu difusi maka semakin besar bahan aktif yang dilepaskan.

Formula sediaan krim terdiri dari tiga konsentrasi ekstrak yang berbeda yaitu F1 $(1,6 \%)$, F2 (0,16\%) dan F3 (0,016\%). Pengukuran aktivitas antioksidan dilakukan sebelum penyimpanan dan setelah penyimpanan. Hasil yang didapatkan formula terbaik sebelum penyimpanan dan setelah penyimpanan adalah formula 3 dengan konsentrasi ekstrak 0,016\%, dimana berdasarkan pengujian Anava satu arah dan uji lanjutan BNJ menghasilkan jumlah rerata tertinggi pada saat sebelum penyimpanan dan setelah penyimpanan.

Konsentrasi terbaik ekstrak dalam sediaan krim kemudian diuji $\mathrm{t}$ untuk melihat perbedaan antara aktivitas sebelum dengan sesudah penyimpanan. Berdasarkan uji t tidak terdapat perbedaan aktivitas antioksidan sediaan krim F3 sebelum dan setelah penyimpanan. Sehingga sediaan krim F3 stabil secara fisik maupun kimianya.

\section{KESIMPULAN}

Krim yang paling stabil secara fisik adalah krim yang mengandung 0,016\% ekstrak etil asetat daun Cempedak (Artocarpus champeden Spreng). Aktivitas antioksidan sediaan krim tidak mengalami perubahan yang signifikan selama penyimpanan, dengan nilai $\mathrm{IC}_{50}$ sebesar 5,91 ppm sebelum penyimpanan dan 10,57 ppm setelah penyimpanan. 


\section{DAFTAR PUSTAKA}

Aisyahni, M. 2012. Formulasi Sediaan Krim Wajah Ekstrak Daun Gambir (Uncaria Gambir Roxb.) dengan Basis Virgin Coconut Oil (VCO). Universitas Islam Bandung: Bandung.

Allen, L. V, Nicholas G. P dan Howard C. Ansel. 2011. Ansel's Pharmaceutical Dosage Forms and Drug Delivery System Ninth Edition. Wolters Kluwer: China.

Anggraini, S., Mita, N., Ibrahim, A., 2015, Formulasi dan Optimasi Basis Krim Tipe a/m dan Aktivitas Antioksidan Daun Cempedak (Artocarpus champeden Spreng), Mulawarman Pharmaceuticals Conference Proceedings, (1), 22-30, Retrieved from http://prosiding.farmasi.unmul.ac.id/index.php/mpc/article/view/4

Anies. 2009. Cepat Tua Akibat Radiasi? Pengaruh Radiasi Elektromagnetik Ponsel dan Berbagai Peralatan Elektronik. PT Elex Media Komputindo: Jakarta.

Anwar, E. 2012. Eksipien dalam Sediaan Farmasi: Karakteristik dan Aplikasi. Penerbit Dian Rakyat: Jakarta.

Barel, A. O, Marc P, dan Howard I. M. 2009. Handbook of Cosmetic Science and Technology Third Edition. Informa Healthcare: New York.

Mita, Nur, 2015, Formulasi Krim dari Kulit Buah Kakao (Theobroma cacao L.) Berkhasiat Antioksidan, Journal of Tropical Pharmacy and Chemistry, [S.I], v.3, n.1, june 2015.

ISSN 2407-6090. Available

at https://jtpc.farmasi.unmul.ac.id/index.php/jtpc/article/view/83.

Pereira, Valeria J. dan Maria A. C. K. 2013. The High Bioactivity of Artocarpus - An Exotic Genus. Floresta e Ambiente ISSN 1415-0980.

Sinko, P. J., 2006, Martin's Physical Pharmacy and Pharmaceutical Science: Physical Chemical and Biopharmaceutical Principle in the PharmaceuticalSciences, $5^{\text {th }}$ edition, Lippicott William and Wilkins, Philadelpia. 